\title{
Performance of Medium term Agro-Forest treespecieson hard Laterite Soils
}

\author{
S.C. Somasiri ${ }^{1,2^{*}}$, M. K. F. Nadheesha ${ }^{3}$ and S. Ediriweera ${ }^{4}$ \\ ${ }^{1}$ Department of Animal and Food Sciences, Faculty of Agriculture, Rajarata University of Sri Lanka, Sri Lanka \\ ${ }^{2}$ Former address:Agronomy Division, Coconut Research Institute, Sri Lanka \\ ${ }^{3}$ Soils and Plant Nutrition Division, Coconut Research Institute, Sri Lanka \\ ${ }^{4}$ Department of Science and Technology, UvaWellassa University, Badulla, Sri Lanka
}

\begin{abstract}
A long term research was initiated in 1999 using medium term agro-forest trees in a shallow Andigama series soils having a hard laterite gravel layer. The present paper focuses on the growth and survival of the medium term forest tree species planted in 1999 and theirperformance by the year 2016. Acacia species had the fastest $(P<0.05)$ growth in terms of tree diameter at breast height (DBH)during the time period (1999-2016) followed byMacarangapeltata, Gliricidia sepium andTectonagrandis. In contrast,Swieteniamacrophyllahad the lowest $(P<0.05)$ growth during the same period. Further, Brideliamoonii had a lower $(P<0.05)$ growth compared to Acacia species and Macarangapeltatabut not different from other species. Thus Acacia species, Macarangapeltata, Gliricidia sepium andTectonagrandis could be selected as better agroforest tree species for medium term basis to be grown in hard laterite soils in Andigama soil series Shallow Phase.
\end{abstract}

Keywords-agroforest tree species,Andigama soil series,hard laterite soils.

\section{INTRODUCTION}

The soils with laterites, a form of rock found in lowlands, uplands and highlands in Sri Lanka, are rich with ferrous, aluminium and silicon oxides due to the weathering process called laterization(Dahanayake, 1982). Depending on the severity of the weathering process these laterites can be either hard laterites or soft laterites. When it is hard laterites it is difficult to use for agricultural purpose unless the laterites are broken into soft laterites. Likewise, it has been noted that the expected growth and the yield could not be achieved when coconutpalms are established in hard laterite soils(CRI Advisory Circular No. 1, 2008). It is mainly due to the shallow top soil layer followed by a hard lateritic layer obstructing coconut roots to penetrate/break into the deeper soil layers.

The Andigama series soil found in Andigama area is one of soils used for cultivating coconuts in Sri Lanka(Somasiri et al., 2006). This soil series belongs to the Red Yellow PodzolicGreat Soil Groupwitha gravel layer. Andigama soil series is divided into three phases considering the depth; Moderately Deep Phase, Shallow to Moderately Deep Phaseand Shallow Phase. Parrotta et al.,(1997) documented thatthere is a possibility of improving soil physical and chemical properties by establishing deep rooted tree plantations.Thus, a research was implemented in 1999 to improve the Andigama soil series Shallow phase using medium term agro forestry tree species.The present paper focuses on the growth and survival of the medium term agro forest tree species planted in 1999

\section{METHODOLOGY}

Experimental site was located at the Rathmalagara Research Centre, Coconut Research Institute (Longitude $7.5^{\circ} 32^{\prime} \mathrm{N}$ and Latitude $79^{\circ} 53^{\prime} \mathrm{E}$ ) in the Puttalam district (North western Province) in agro-ecological zone $\mathrm{IL}_{1 \mathrm{a}}$ in the intermediate low country, Sri Lanka(Punniyawardena, 2008).

Ten medium term agro forest tree species that were commonly found in the area were planted in an area of one hectarein a layout of Randomized Complete Block Design with three replicatesin October 1999 (Table 1).Initially one replicate had 10 plants of the respective species. The soil series at the site was Andigama soil series Shallow Phase with a hard laterite gravellayer at various depths. The initial depth of top soil was $15 \mathrm{~cm}$ in average.

Table.1: The scientific names of 10 forest tree species selected for the study in 1999

\begin{tabular}{ll}
\hline Species & Family \\
\hline Acacia auriculiformis & Fabaceae \\
Acacia mangium provenance 1 & Fabaceae \\
Acacia mangiumprovenance 2 & Fabaceae \\
Calophylluminophyllum & Clusiaceae \\
Grewiatiliifolia & Tiliaceae \\
Macarangapeltata & Euphorbiaceae \\
Gliricidia sepium & Fabaceae \\
Tectonagrandis & Lamiaceae \\
Swieteniamacrophylla & Meliaceae
\end{tabular}




Brideliaretusa Euphorbiaceae

One year old seedlings of each specieswere planted in a 30x30x30 cm planting hole. Spacingbetween plants varied depending on the plant species i.e.Gliricidia sepium $2 \times 1$ $\mathrm{m}$,Acacia species $2 \times 2 \mathrm{~m}$ and for other species $2.5 \times 2.5 \mathrm{~m}$ between and within row spacing.Plants were monitored closely and irrigated whenever,needed at the seedling stage.

However, by the end of year 2002, only one replicate of Grewiatiliifoliaand Calophyllumelatumspecies survived at the experimental site. Therefore, neither of those two species considered as a treatment in the present paper. Further,even though all replicates of the three Acacia species survived up to the year 2016, all three Acaciaspecies were considered as one treatment and randomnly selected any Acacia species from any block for data collection.At the beginning of experiment the parameters such as leaf litter content, weed biomass, weed species and soil organic matter contents were measured inconsistently. These data were presented and used in the discussion of this paper for the mere understanding of the growth and survival of these agro forest tree species. Tree girth at breast height $(\mathrm{GBH})$ was measured at two heights (30 $\mathrm{cm}$ and $130 \mathrm{~cm}$ ) above ground using a tapeduring the years 2000, 2002, 2003 and 2016. Later, all GBH values were converted to diameter at breast height values (DBH). Tree diameter measurements were analysed using repeated measure analysis using the procedure for general linear model (proc GLM) in SAS version 9.1 (SAS, 2002). The means were separated using least significant difference (LSD) procedure in proc GLM.

\section{RESULTS AND DISCUSSION}

Six medium term forest tree species Acacia species, Macarangapeltata (Kenda),Gliricidia sepium, Swieteniamacrophylla (Mahogany), Brideliamoonii (Ketakela) and Tectonagrandis (Teak)survived during the period 1999 to 2016 except Grewiatiliifoliaand Calophyllumelatumas mentioned above.

Calophyllumelatum(Dombe) and Grewiatiliifolia (Damminna)did not survive after the year 2002. The reason could be the hard laterite soils presence at the experimental site was not supportive for their natural growth as Eldridge et al.,(1994)observed withEucalyptus degluptaspecies. The above authors havenoted that Eucalyptusdegluptawould not survivein degraded soils as it thrives in well-drained tropical alluvial soils naturally. Similarly, Calophyllumelatum and Grewiatiliifoliamay not be successful in hard laterite soils.It was documented inAnnual Report(2000), Calophyllumelatum had the lowest growth rate and was susceptible to drought and pests during the early growth stages. Thus Calophyllumeletum being grown in an unfavourable hard laterite soils plus its inability to withstand the drought and pest conditions could be the reasons for not surviving at the experimental site.

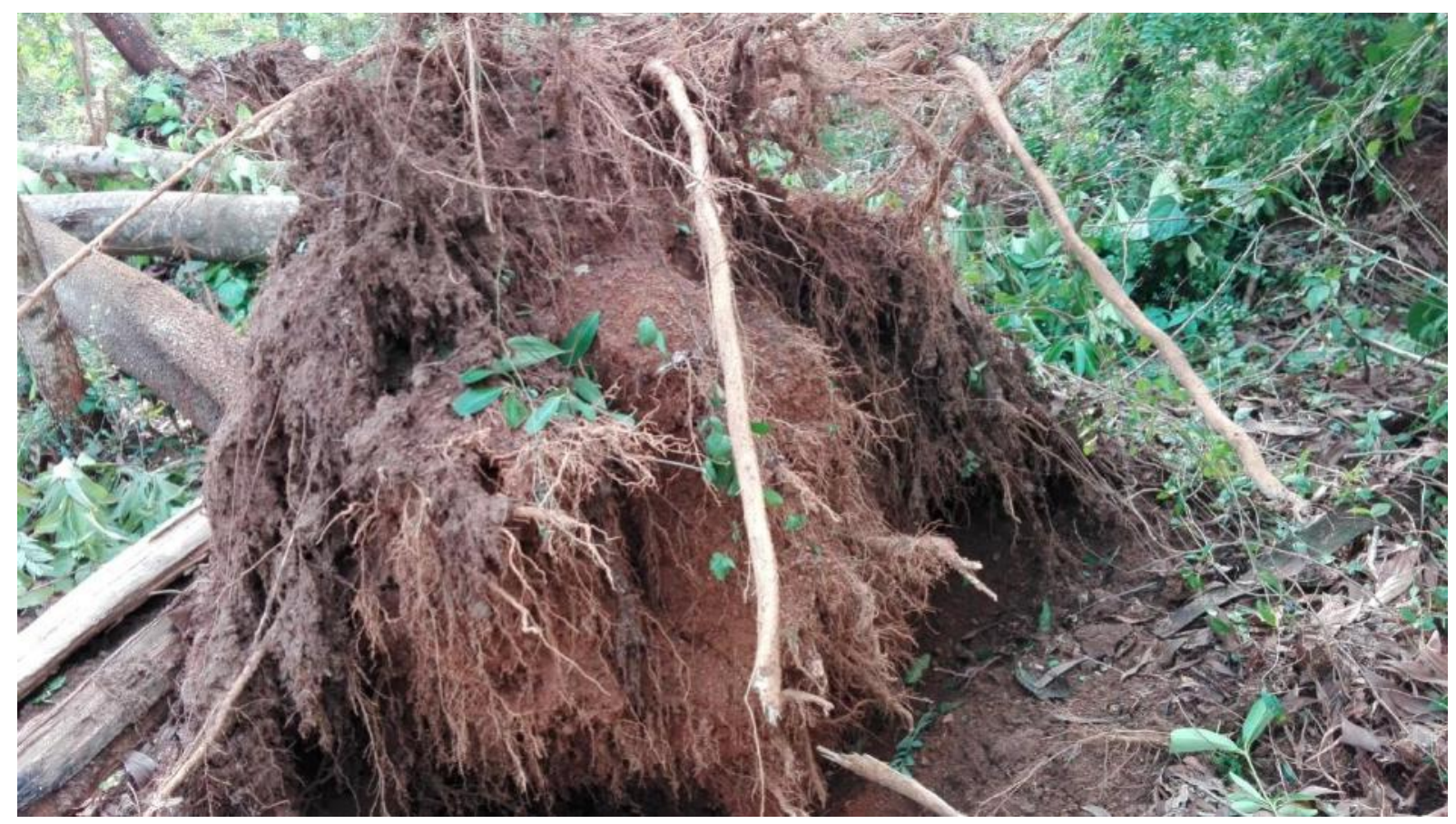

Fig.1: An uprooted Acacia tree at the experimental site in 2016

By the mid of year 2016, there werenumber of trees of Acacia species, Macarangapeltata (Kenda), Gliricidia sepium (Gliricidia), Brideliamoonii (Ketakela) and Tectonagrandis(Teak)were fallendue to the effect of a 
minor cyclone that swept through the area during May, 2016.Field observations showed that the tap rootwas hard to distinguish in these uprooted trees (Figure 1). It may be due to the hard laterite layer at the experimental site

Diameter at $30 \mathrm{~cm}$ and $130 \mathrm{~cm}$ of the agro forest tree species in year 2000 and 2016 are given in Table 2. By the end of year 2000, Acacia species and Macarangapeltatawere having significantly higher diameter at $30 \mathrm{~cm}$ and $130 \mathrm{~cm}$ heights in comparison with other agro forest tree species.In 2016,Acacia species reached the highest $(\mathrm{P}<0.05)$ growth rate compared to Macarangapeltata which in turn was higher $(\mathrm{P}<0.05)$ than that of Gliricidia sepium, Swieteniamacrophylla, Brideliamooniiand Tectonagrandis. Swieteniamacrophyllahad the lowest $(\mathrm{P}<0.05)$ growth rate in 2016 after approximately 17 years of planting. Gliricidia sepium and Tectonagrandishad similar growth rates in 2016 while, the growth rate of Brideliamoonii was different $(\mathrm{P}<0.05)$ from Acacia species and Macarangapeltatabut not differ $(\mathrm{P}>0.05)$ from other tree species.

During the early stage of the experiment leaf litter content, weed biomass, light availability at ground level and soil organic matter percentage were measured. The obstructing the downward penetration of the tap root damaging its tip and causing it to branch as it grows as observed by Dobson(1995).

data is presented in Table 3. Annual Report(2001) showedthat Acacia mangium provenance 2 had significantly higher $(\mathrm{P}<0.05)$ leaf litter content in the year 2001. Acacia auriculiformis, Swieteniamacrophylla and Brideliamooniihad the lowest $(\mathrm{P}<0.05)$ leaf litter content compared to Acacia mangium provenance 2 (Annual Report 2001). The leaf litter content in Acacia mangium provenance 1, Macarangapeltata, Gliricidia sepium and Tectonagrandis were similar. However, by the year 2016(Table 4) leaf litter content of Tectonagrandis was higher $\quad(\mathrm{P}<0.05) \quad$ than Acaia species, Swieteniamacrophylla,Brideliamooniiand

Macarangapeltatabut not different from Gliricidia sepium(Bandara et al., 2017). Lugo et al.,(1991) observed that the floor litter content in a tropical plantation having indigenous tree species ranges from 500 to $2800 \mathrm{~g} \mathrm{per}^{2}$. Further, supporting the above finding,Stanley and Montagnini,(1999) stated that leaf litter accumulation in soils varies within a year depending on tree species supporting the findings of the present study.

Table.2: Tree diameter (cm) measurements of the forest tree species

\begin{tabular}{|c|c|c|c|c|c|}
\hline & \multirow[t]{3}{*}{ Forest tree species } & \multicolumn{4}{|c|}{ Year } \\
\hline & & \multicolumn{2}{|c|}{2000} & \multicolumn{2}{|c|}{2016} \\
\hline & & $\begin{array}{c}\text { Diameter at } 30 \\
\text { cm }\end{array}$ & $\begin{array}{c}\text { Diameter at } \\
130 \mathrm{~cm}\end{array}$ & $\begin{array}{c}\text { Diameter at } 30 \\
\text { cm }\end{array}$ & $\begin{array}{c}\text { Diameter at } 130 \\
\text { cm }\end{array}$ \\
\hline 1 & Acacia species & $13.18^{b} \pm 0.86$ & $11.11^{b} \pm 0.86$ & $40.33^{\mathrm{d}} \pm 0.91$ & $35.74^{d} \pm 0.86$ \\
\hline 2 & Macarangapeltata (Kenda) & $12.59^{b} \pm 0.86$ & $10.63^{b} \pm 0.86$ & $30.31^{\mathrm{c}} \pm 0.86$ & $28.44^{c} \pm 0.86$ \\
\hline 3 & Gliricidia sepium & $6.93^{a} \pm 0.86$ & $5.86^{\mathrm{a}} \pm 0.86$ & $27.25^{b} \pm 0.86$ & $22.89^{\mathrm{ab}} \pm 0.86$ \\
\hline 4 & $\begin{array}{l}\text { Swieteniamacrophylla } \\
\text { (Mahogany) }\end{array}$ & $4.97^{\mathrm{a}} \pm 0.86$ & $3.83^{\mathrm{a}} \pm 0.86$ & $24.43^{\mathrm{a}} \pm 0.86$ & $21.10^{\mathrm{a}} \pm 0.86$ \\
\hline 5 & Brideliamoonii (Ketakela) & $5.11^{\mathrm{a}} \pm 0.86$ & $4.19 \mathrm{a} \pm 0.86$ & $25.40^{\mathrm{ab}} \pm 0.89$ & $22.91^{\mathrm{ab}} \pm 0.86$ \\
\hline 6 & Tectonagrandis (Teak) & $6.97^{\mathrm{a}} \pm 0.86$ & $4.08^{a} \pm 0.86$ & $27.32^{\mathrm{b}} \pm 0.86$ & $24.28^{b} \pm 0.86$ \\
\hline
\end{tabular}

Different superscripts within columns differ significantly (a,b,c,d: $\mathrm{P}<0.05)$

Table.3: Leaf litter content, weed biomass level and Light availability at ground level and soil organic matter levels in the experimental site during the early stages of growth.

\begin{tabular}{|c|c|c|c|c|c|}
\hline & \multirow[t]{2}{*}{ Forest tree species } & $2001^{(1)}$ & $2002^{(2)}$ & $2002^{(2)}$ & $2005^{(3)}$ \\
\hline & & $\begin{array}{c}\text { Leaf litter } \\
\text { (Dry Weight } \\
\text { basis }(\mathrm{g} / \mathrm{m} 2)\end{array}$ & $\begin{array}{l}\text { Weed biomass } \\
\qquad\left(\mathrm{g} / \mathrm{m}^{2}\right)\end{array}$ & $\begin{array}{c}\text { Light availability } \\
\text { at ground level } \\
(\text { lumen/m²) }\end{array}$ & $\begin{array}{c}\text { Soil organic } \\
\text { matter } \\
(\%)\end{array}$ \\
\hline 1 & Acacia auriculiformis & $92^{\mathrm{a}}$ & 63 & 13 & 2.3 \\
\hline 2 & Acacia mangium-provenance 1 & $327^{\mathrm{bc}}$ & 20 & 16 & 2.9 \\
\hline 3 & Acacia mangium-provenance 2 & $488^{c}$ & 27 & 18 & 2.4 \\
\hline 4 & Macarangapeltata (Kenda) & $188^{\mathrm{ab}}$ & 13 & 6 & 2.3 \\
\hline 5 & Gliricidia sepium & $156^{\mathrm{ab}}$ & 16 & 3 & 3.4 \\
\hline
\end{tabular}


6 Swieteniamacrophylla (Mahogany)

7 Brideliamoonii (Ketakela)

8 Tectonagrandis (Teak)

Level of significance
LSD $(\mathrm{P}=0.05)$

\section{$90^{\mathrm{a}}$}

$120^{\mathrm{a}}$

$175^{\mathrm{ab}}$

$* * *$

Note: Data in this table was obtained from the Annual Reports publ

$* * * \mathrm{P}=0.05 * \mathrm{P}=0.01$

Table.4: Leaf litter content at different forest tree species at the experimental sitein 2016

\begin{tabular}{|c|c|c|}
\hline Treatment & Leaf litter $\left(\mathrm{g} / \mathrm{m}^{2}\right)$ & $\begin{array}{c}\text { Soil Organic Carbon percentage } \\
(\%)\end{array}$ \\
\hline Acacia spp & $2085^{a} \pm 415$ & $1.89^{c} \pm 0.09$ \\
\hline Brideliamoonii & $2011^{\mathrm{a}} \pm 415$ & $1.55^{\mathrm{a}} \pm 0.09$ \\
\hline Swieteniamacrophylla & $2040^{\mathrm{a}} \pm 415$ & $1.78^{\mathrm{abc}} \pm 0.09$ \\
\hline Tectonagrandis, & $3321^{\mathrm{b}} \pm 415$ & $1.61^{b c} \pm 0.09$ \\
\hline Macarangapeltata & $2050^{\mathrm{a}} \pm 415$ & $1.83^{a b} \pm 0.09$ \\
\hline Gliricidia sepium & $2374^{\mathrm{ab}} \pm 415$ & $1.77^{\mathrm{abc}} \pm 0.09$ \\
\hline
\end{tabular}

Different superscripts within columns differ significantly (a,b,c: $\mathrm{P}<0.05)$

Source: Bandara et al.,(2017)

It had been noted that the weed growth was lower $(\mathrm{P}<0.05)$ in the plots with Acacia species and Macarangapeltatain 2000(Annual Report, 2000). However, by the year 2002, weed biomass per $\mathrm{m}^{2}($ Table 3$)$ were higher $(\mathrm{P}<0.05)$ in Swieteniamacrophylla, Tectonagrandis and Brideliamoonii compared toMacarangapeltata, Gliricidia sepium and Acacia species (Annual Report, 2002).Thus, higher the light availability at ground level, higher the weed biomass allowing favourable conditions for the growth of weeds (Table 3). This is also supported by the slower growth rates of these forest tree species (SwieteniamacrophyllaIand Brideliamoonii). Similarly, Swieteniamacrophylla has a higher $(\mathrm{P}<0.05)$ weed density than Acacia auriculiformiswhich in turnhad a higher $(\mathrm{P}<0.05)$ weed density than Tectonagrandis(Annual Report, 2004). Weed density in other forest tree species were significantly lower $(\mathrm{P}<0.05)$. Lowest weed density was observed in plots with Gliricidia sepium(Annual Report, 2004). It may be due to the lower light availability at ground level (Table 3 ) restricting the growth of weeds in the Gliricidia plots.

Soil organic matter content in the year 2005(Table 3) was not significantly different among treatments (Annual Report, 2005). However, by the year 2016(Table 4) Acacia species had a higher $(\mathrm{P}<0.05)$ soil organic carbon percentage (SOC\%) compared to Brideliamoonii. It was observed that accumulation of leaf litter has not directly influencedon the SOC\%.This may be because depending on the forest tree species the rate of decomposition varies along the year as suggested by Stanley andMontagnini
(1999). According to the above Authors even though PithecellobiumelegansandVochysiaferraineaproducers a larger amount of floor litter content with higher organic matter content, both species have different decomposition rates.P. elegans has a higher decomposition rate whereas, species such as V.ferrainea has a slower decomposition rate (Stanley \& Montagnini, 1999).

\section{CONCLUSION}

Calophyllumelatum and Grewiatiliifolia did not survive beyond year 2002 could be due to the hard laterite soils being not their naturally favourable soils, susceptibility for drought and competition from other forest tree and weed species.Acacia species had the fastest growth during the time period (1999-2016) followed byMacarangapeltata, Gliricidia sepium andTectonagrandis. In contrast, Swieteniamacrophylla had the lowest growth during the same period. Further,Brideliamoonii had a lower growth compared to Acacia species and Macarangapeltata but not different from other species.Thus Acacia species, Macarangapeltata, Gliricidia sepium andTectonagrandis could be selected as better agro-forest tree species for medium term basis to be grown in hard laterite soils in Andigama soil series Shallow Phase.

\section{ACKNOWLEDGEMENT}

Authors wish to acknowledge present and past Directors of the Coconut Research Institute, Sri Lanka for funding the research. The research group Dr K.B. Dassanayake, Agronomist and Mr H.A. Abeysoma, Technical Officer of 
the Agronomy Division who initiated this long term research in 1999 are acknowledged. Presently, Mr W.M. Nuwan, Technical Officer and Mr Arosh Ranganath Field Assistant from the Agronomy Division are acknowledged for their assistance in the Data collection.

\section{REFERENCES}

[1] Annual Report. (2000). Report of the Agronomy Division. Coconut Research Institute, Lunuwila, Sri Lanka.

[2] Annual Report. (2001). Report of the Agronomy Division. Coconut Research Institute, Lunuwila, Sri Lanka. 32-33.

[3] Annual Report. (2002). Report of the Agronomy Division. Coconut Research Institute Lunuwila, Sri Lanka. 44-45.

[4] Annual Report. (2004). Report of the Agronomy Division. Coconut Research Institute, Lunuwila, Sri Lanka. 38-39.

[5] Annual Report. (2005). Report of the Agronomy Division. Coconut Research Institute, Lunuwila, Sri Lanka. 29-30.

[6] Bandara U. M. S. A. M., F.Nadheesha M. K., Somasiri S. C., Amarashinghe K. G. A. P. K. (2017). Assessment of Soil Organic Carbon Levels in Hard Laterite Coconut Growing Soil Having Medium Rotation Agro Forestry Trees. Proceedings of the 16th Agricultural Research Symposium 1-5.

[7] CRI Advisory Circular No. 1. (2008). CRI Advisory Circular No. 1. Use of fertilizer for culivation of coconuts and land suitability.

[8] Dahanayake Kapila. (1982). Laterites of Sri Lankaa reconnaissance study. Mineralium Deposita17: 245-256.

[9] Dobson M. (1995). Tree Root Systems. Arboricultural Advisory and Information Service, Alice Holt Lodge, Wrecclesham, Farnham, Surrey, Gu104 LH

[10]Eldridge K., Davidson J., Harwood C., Wyk G. van. (1994). Eucalypt Domestication and Breeding. Clarendon Press. Oxford.

[11]Lugo A.E., Cuevas E., SaÂnchez M.J. (1991). Nutrients and mass in litter and top soil of ten tropical tree plantations. Plant and Soil125: 263-280.

[12] Parrotta John A., Turnbull John W., Norman J. (1997). Catalyzing native forest regeneration on degraded tropical lands. Forest Ecology and Management99: 1-7.

[13] Punniyawardena B.V.R. (2008). Rainfall pattern in Sri Lanka and agro-ecologocal zones. Department of Agricultre: pp. 25-75.

[14] SAS (2002) 'SAS 9.1.' (SAS Institute Inc.: Cary, $\mathrm{NC})$.
[15] Somasiri L.L.W., Nadarajah N., Amarasinghe L., Gunathilake H.A.J. (2006). Land suitability assessment of coconut growing areas in the coconut triangle. Coconut Research Institute of Sri Lanka, Lunuwila.

[16] Stanley William G., Montagnini Florencia. (1999). Biomass and nutrient accumulation in pure and mixed plantations of indigenous tree species grown on poor soils in the humid tropics of Costa Rica. Forest Ecology and Management113: 91-103. 